\title{
Monimenetelmäinen tutkimus toimittajien kielikäsityksistä ja kielenhuoltodiskursseista
}

\begin{abstract}
Maija Saviniemi: On noloa, jos ammattilaiset tekevät tökeröitä kielivirheitä. Toimitushenkilökunnan kielenhuoltotiedot, -käytännöt ja -diskurssit. Acta Universitatis Ouluensis. B Humaniora 127. Oulu: Oulun yliopisto 2015. 326 s. + liitteet.

ISBN 978-952-62-0776-6.
\end{abstract}

Maija Saviniemen väitöskirja On noloa jos ammattilaiset tekevät tökeröitä kielivirheitä. Toimitushenkilökunnan kielenhuoltotiedot, -käytännöt ja -diskurssit käsittelee toimitushenkilökunnan suhtautumista kielenhuoltoon. Saviniemi selvittää, millaisia kielenhuoltoa koskevia käsityksiä, tietoja ja työskentelykäytäntöjä lehtien ja Yleisradion toimitushenkilökunnalla on ja millaisia kielenhuoltodiskursseja toimitushenkilökunnan puheesta on löydettävissä. Tutkimuskohteena ovat paikallis- ja sanomalehtien sekä Yleisradion toimitushenkilökunnan kielenhuoltoa koskevat tiedot ja asenteet. Saviniemi tarttuu tutkimuksessaan aiheeseen, jota ei ole Suomessa tässä laajuudessa ja näin perusteellisesti aiemmin tutkittu. Aihe on kiinnostava paitsi suomen kielen tutkijoille myös toimittajille, toimittajien kouluttajille ja muille kielen ammattilaisille. Saviniemen tutkimuksella on soveltava tavoite (s. 109): pyrkimyksenä on paitsi herättää keskustelua toimitusten kielenhuollosta myös tarjota tuloksia, joita voisi soveltaa äidinkielen ja kielenhuollon opetuksessa, toimittajien koulutuksessa sekä suomen kielen lautakunnan työssä.
Saviniemi asettaa kolme tutkimuskysymystä: 1) millaisia toimitushenkilökunnan kielenhuoltotiedot ovat, 2) millaisia kielenhuoltokäytäntöjä toimituksissa on ja 3) millaisia kielenhuoltodiskursseja toimitushenkilökunta rakentaa sekä millaisia kieliasenteita niistä voidaan lukea (s. 109)? Näitä kysymyksiä ja siten toimitushenkilökunnan kielenhuoltoasenteita Saviniemi selvittää analysoimalla vuosina 2002 ja 2004 tehdyn kyselytutkimuksen vastauslomakkeita määrällisesti ja laadullisesti.

Saviniemen väitöskirja on monografiaksikin hyvin laaja, liitteineen yhteensä 411 sivua. Työn rakenne on kuitenkin selkeä ja tasapainoinen: Luvussa 1 esitellään työn tausta ja lähtökohdat, luvussa 2 keskeiset käsitteet, suomalaisen kielenhuollon historia ja pääperiaatteet sekä viestinten kieli ja aiempi tutkimus. Luvuissa 3 ja 4 kuvataan aineisto, teoria ja menetelmät. Nämä ensimmäiset luvut vievät työn leipätekstistä noin runsaan kolmasosan. Seuraavat kolme analyysilukua (5-7) vastaavat kukin yhteen esitettyyn tutkimuskysymykseen, ja loppuluvun (8) kanssa ne vievät leipätekstistä noin kaksi kolmasosaa. Työtä paisuttavatkin erityisesti liitteet, joissa on mukana laajasti aineistonhankintaan liittyviä lomakkeita ja viestejä sekä laadullisen analyysin yksityiskohtainen erittely kokonaisuudessaan.

Saviniemen tutkimus jatkaa suomalaista kielenhuoltoa käsittelevää tutkimusta, jota ovat 200o-luvulla edustaneet esimerkiksi Anne Mäntysen (2003) ja 
Taru Viinikaisen (2010) väitöskirjat. Samalla se osallistuu keskusteluun, jota on käyty suomen kielen huollon periaatteista ja käytännöistä jo 180o-luvun lopulta alkaen ja käydään edelleen. 1900-luvun loppupuolella tässä keskustelussa keskeisiä ovat olleet esimerkiksi Pentti Leinon (esim. 1989), Paula Sajavaaran (2000), Päivi Rintalan (esim. 1998), Harri Mantilan (esim. 2005) ja Pirjo Hiidenmaan (2003) kirjoitukset; keskusteluun liittyy myös vuonna 2014 ilmestynyt Taru Kolehmaisen kielenhuollon historiaa valottava teos Kielenhuollon juurilla. Tähän suomen kielen huollon periaatteista käytyyn käytännölliseen ja teoreettiseen keskusteluun Saviniemi on erinomaisesti perehtynyt, mikä luo hyvän pohjan hänen omalle tutkimukselleen.

\section{Diskursiivinen näkökulma kansan- lingvistiikkaan}

Väitöskirjan teoreettinen tausta rakentuu kansanlingvistiikan ja kriittisen diskurssianalyysin yhdistelmästä, joka on fennistiikassa nähdäkseni uusi lähestymistapa ja osoittautuu hedelmälliseksi. Teoreettisesti ja menetelmällisesti tutkimus edustaa erityisesti kansanlingvististä kieliasennetutkimusta, jota ovat Suomessa tehneet muun muassa Aila Mielikäinen ja Marjatta Palander (esim. 2014) sekä väitöskirjatutkimuksissaan Johanna Vaattovaara (2009) ja Anne-Maria Nupponen (2011). Saviniemen tutkimus on kuitenkin ensimmäinen, jossa kansanlingvististä tarkastelutapaa käytetään standardikielen tutkimuksessa; aiemmat tutkimukset ovat koskeneet suomen murteita. Kiinnostavaa ja uutta on myös se, että Saviniemi soveltaa kansanlingvististä näkökulmaa toimitushenkilökuntaan, jonka voi olettaa olevan kielitietoisempaa kuin niin sanotun naiivin kielenkäyttäjän. Toimitustyön keskiössähän on nimenomaan kieli, mikä saattaa vaikuttaa myös siihen, miten toimituksissa kieleen suhtaudutaan.
Lisäksi tutkimuksessa hyödynnetään kriittisen diskurssianalyysin periaatteita, joita ovat suomen kielen väitöskirjoissaan soveltaneet erityisesti Pirjo Karvonen (1995), Vesa Heikkinen (1999), Pekka Pälli (2003) ja Eija Paso (2007). Kaikkiaan Saviniemi nojaa tutkimuksessaan vahvasti erityisesti suomalaiseen kielenhuollon tutkimukseen ja kansanlingvistiikan sekä diskurssintutkimuksen peruskirjallisuuteen, kuten Norman Faircloughin (esim. 1992) kriittisen diskurssianalyysin malliin. Kriittinen diskurssianalyysi kytkeytyy Saviniemen tutkimuksessa erityisesti diskurssin käsitteeseen ja ymmärrykseen kielenkäytöstä sosiaalisena ja kielellisenä toimintana, joka rakentaa todellisuutta. Lisäksi juuri se tarjoaa perustan aineiston laadulliselle analyysille, jolla Saviniemi erittelee vastauksissa rakentuvia kielenhuoltodiskursseja.

Teoriataustan valinta on perusteltu hyvin, vaikka hieman ongelmallisena voi pitää kansanlingvistiikan soveltamista toimitushenkilöstön asenteiden tutkimukseen. Kansanlingvistiikan tutkimuskohteena ovat nimittäin maallikoiden eli ei-kielitieteilijöiden havainnot ja käsitykset kielestä, ja alan tutkimus koskee tyypillisesti puhuttua kieltä. Kuten Saviniemi itsekin toteaa, toimitushenkilöstöä ei kuitenkaan voi yksiselitteisesti pitää maallikkoina, ja siksi hän nimittääkin heitä semimaallikoiksi (s. 17) - siis ikään kuin osittaisiksi maallikoiksi. Tältä osin kokonaisuutta olisi voinut täydentää lingvistisestä antropologiasta lähtenyt kieli-ideologioiden tutkimus, jossa kielenkäyttäjiä lähestytään kielikäsitysten kannalta ikään kuin samanarvoisina. On toisaalta huomautettava, että Saviniemi ottaa kansanlingvistiikan rajoitukset taitavasti huomioon analyysia ja päätelmiä tehdessään ja viittaa kyllä kieliideologioiden tutkimukseen lyhyesti. Tutkimus osuu joka tapauksessa teoreettisesti ja ideologisesti kiinnostavaan kysymykseen: Voiko ja onko mielekästä aja- 
tella, että kielitieteilijöiden ja maallikoiden käsitykset kielestä tai kieliasenteet eroavat toisistaan? Ja toisaalta: millaista kielitietoa on kielen ammattilaisilla, joille kieli on jokapäiväinen ja keskeinen ammattiväline?

Saviniemen tutkimuksen keskeisiä käsitteitä ovat muun muassa kielenhuolto, toimitushenkilökunta, diskurssi sekä erilaiset suhtautumista kuvaavat käsitteet erityisesti kieliasenne, kielikäsitys ja kieliideologia. Saviniemi määrittelee käsitteet selvästi, vaikka hieman epäselväksi jääkin esimerkiksi se, ovatko kieliasenne ja kieli-ideologia yksilön vai yhteisön tason käsitteitä ja missä määrin niissä on kysymys tiedosta ja missä määrin suhtautumisesta tai reaktiosta. Myös kielikäsityksen ja kieli-ideologian käsitteiden välinen ero jää kunnolla eksplikoimatta ja herää kysymys, ovatko ne vain eri tapa ilmaista sama asia - vai tosiaan eri asia.

\section{Yksi aineisto - monta menetelmää}

Saviniemen tutkimuksen aineisto on kerätty paikallislehtien, sanomalehtien ja Yleisradion toimituksille sähköpostitse tehdyllä kyselyllä, jossa oli sekä suljettuja että avoimia kysymyksiä. Kyselyaineisto koostuu yhteensä 232 vastauslomakkeesta. Aineistoa analysoidaan sekä määrällisesti että laadullisesti - kuitenkin niin, että laadullinen analyysi kohdistuu nimenomaan kyselyssä saatuihin vastauksiin, joissa informantit perustelivat, miksi he pitävät kielenhuoltoa erittäin tai melko tärkeänä. Aineisto on kuvattu ja sen valinta ja keruu raportoitu poikkeuksellisen tarkasti ja yksityiskohtaisesti, mitä voi pitää yhtenä tutkimuksen ansioista. Aineiston eli kyselyyn vastanneiden informanttien jakauma esitellään alueellisesti, ikäryhmittäin, sukupuolittain ja tehtävänimikkeittäin, ja sitä voi ilman muuta pitää edustavana. Informanttien alueellisessa jakautumisessa huomiota herättää kuitenkin se, että suurimmista seutukunnista esimerkiksi Tam- pereen ja Oulun seuduilta vastauksia sanomalehtien toimituksista on vain yksi, kun esimerkiksi Keski-Suomesta ja Vaasan seudulta vastauksia on neljästä viiteen ja yhdestä Savon seudun kohteesta jopa 14 (liite 4 s. 337). Tämä kertonee ehkä siitä, miten eri tavoin toimituksissa on kyselyyn reagoitu ja kenelle vastaaminen on sälytetty. Kysely ja siinä kysytyt suljetut ja avoimet kysymykset sopivat tutkimuksen tarkoituksiin hyvin. Informanteilta kysyttiin muun muassa sitä, mistä he ovat saaneet kielenhuollon tietonsa, millaisia apuneuvoja kielenhuollossa käytetään, millaisia kielenhuolto-ongelmia työssä kohdataan ja miten herkästi kielivirheisiin puututaan.

Saviniemen työn varsinaisina tutkimusmenetelminä ovat kyselytutkimus, sisällönanalyysi ja kriittinen diskurssianalyysi. Näistä kolmesta kyselytutkimus on menetelmä, jolla on hankittu tutkimuksen varsinainen aineisto eli informanttien vastaukset. Vastausten analyysissa taas käytetään määrällistä ja laadullista analyysia, joita sitten yhdistellään tutkimuksessa. Esimerkiksi kyselyn vastauksissa mainituista kielenhuolto-ongelmien määristä esitetään luvussa 5 taulukkoja, mutta lisäksi vastauksia eritellään sisällöllisesti. Määrällisen ja sisällönanalyysin yhdistelmä näkyy myös analyysiluvussa 6. Diskursseja tarkasteleva luku 7 taas keskittyy sanaston ja kieliopin analyysiin kriittisen diskurssianalyysin keinoin, mutta lisäksi siinä esitetään diskursseista myös määrällistä tietoa.

Vaikka fennistiikassa on aiemminkin yhdistelty laadullista ja määrällistä tutkimusta, tämänkaltainen yhdistelmä on uusi ja jopa innovatiivinen. Sekä kyselytutkimus että sisällönanalyysi ovat nimittäin olleet suomen kielen tutkimuksessa jokseenkin harvinaisia - jopa poikkeuksellisia - todennäköisesti siksi, että tutkimuksen fokus on yleensä ollut pääosin kielenainesten lingvistisessä analyysissa. Menetelmällisesti Saviniemen tutkimus toimiikin keskustelunavauksena 
fennistiikassa, jossa on perinteisesti käytetty autenttista eli ilman koejärjestelyitä tuotettua aineistoa tai kirjoitettua aineistoa, esimerkiksi keskustelua tai lehtitekstejä. Myös kyselytutkimuksen aineistoa voi kuitenkin pitää autenttisena, minkä Saviniemi perustelee uskottavasti (s. 29). Itse analyysi on huolellista ja yksityiskohtaista; esimerkiksi diskurssien erittelyn pohjana oleva sanaston ja kieliopin analyysi on esitetty kokonaisuudessaan liitteessä 6. Näin lukija voi halutessaan tarkastella ja arvioida analyysin osuvuutta ja luotettavuutta itse; Saviniemen analyysitaulukot tarjonnevat myös kiinnostavan esimerkin tekstianalyysin opetukseen. Pienenä puutteena analyysissa pidän sitä, että tekstuaalinen metafunktio (Faircloughin mallin mukaan "tekstirakenteet") on jätetty diskurssianalyysista pois. Näin esimerkiksi perustelevat ja kausaaliset suhteet jäävät vastauksista analysoimatta, vaikka niitä voi pitää diskurssien ja kieli-ideologioiden rakentumisessa oleellisina.

\section{Miksi kielenhuolto on tärkeää?}

Saviniemen väitöskirjan keskeinen tutkimustulos ovat vastauksissa rakentuvat kielenhuoltodiskurssit, jotka heijastelevat informanttien asennetta kieleen ja kielenhuoltoon. Näitä diskursseja on selvitetty analysoimalla informanttien vastaukset kysymykseen Miksi [pidätte kielenhuoltoa tärkeänä tai erittäin tärkeänä]? laadullisen diskurssianalyysin keinoin. Diskursseja on yhteensä kuusi erilaista, ja niistä yleisintä Saviniemi nimittää laatudiskurssiksi (Kieli on lehden laadun tae). Laatudiskurssi nostaa esiin nimenomaan journalistisen näkökulman kieleen ja kielenhuoltoon, jolloin hyvä tai huono kieli kytketään siis viestimen imagoon, laatuun ja tasokkuuteen ynnä muuhun. Tämä oli esimerkiksi Yleisradion vastaajilla selvästi yleisin diskurssi. Muita diskursseja ovat vuorovaikutus-, vastuu-, vä- line-, tunne- ja vaalimisdiskurssi, joista osa voi myös lomittua keskenään silloin kun diskurssit eivät ole toistensa ideologisia vastakohtia (kuten esimerkiksi kielen vaalimisen ja kielen välineellistämisen diskurssi ovat).

Kaikkiaan analyysin pohjalta syntyy toimitushenkilöstön kielenhuoltodiskursseista kiinnostava kokonaiskuva, jossa risteilevät paitsi funktionaaliset ja välineelliset myös tunteelliset ja suomen kielen vaalimista korostavat näkemykset. Tutkimuksesta käy ilmi monia kiintoisia asioita, ja siinä on lukuisia yksittäisiä tuloksia, joilla on merkitystä suomen kielen tutkimukselle ja tutkijoille. Se, että toimitushenkilöstö suhtautuu kielenhuoltoon myönteisesti, ei ehkä ole yllätys, mutta tuloksena se on kiinnostava ja fennisteille merkittävä tieto. Se, että koulutustausta korreloi myönteisen kielenhuoltoasenteen kanssa, todistaa, että koulutuksella on väliä. Tähän taas liittyy se ehkä yllättäväkin yksityiskohta, että käytännön työn ja kielenhuollon merkityksen ymmärtämisen kannalta kielenhuollon auktoriteetti tai jonkinlainen kielenhuollon henkilöityminen - tämän tutkimuksen aineistossa Terho Itkoseen, Tampereen yliopiston toimittajakoulutuksen kielenhuollon opettajaan Liisa Manniseen tai Yleisradion Arvi Lindiin - on Saviniemen tutkimuksen perusteella tärkeää. Henkilöityminenhän lienee asia, jota kielenhuoltajat ovat itse usein pyrkineet välttämään.

\section{Lopuksi}

Saviniemen väitöskirja on tutkimusasetelmaltaan kiinnostava ja omaperäinen. Sen tutkimuskohteena ei ole kieli järjestelmänä tai rakenteena eikä kielenkäyttö vaan kieleen liittyvät tiedot ja käsitykset sekä ammattikäytänteet, joiden selvittämiseksi Saviniemi yhdistelee eri teorioita ja menetelmiä. Aineisto on kyselytutkimuksella kerätty, ja sitä 
analysoidaan monesta näkökulmasta eri menetelmin. Asetelmaa voi pitää tyypillisenä soveltavalle kielentutkimukselle mutta harvinaisena fennistiikalle. Tutkimus koskettelee kiinnostavalla tavalla juuri sitä kielentutkimuksen ja kielipolitiikan aluetta, joka on kaikille yhteinen, eli ihmisten suhtautumista kielenhuoltoon. Se on myös viestinnän ja journalismin tutkimusta. Jokainen toimittaja tai toimitustyötä tekevä henkilö työskentelee kielen kanssa ja on siinä mielessä kielen ammattilainen: työtä tehdään nimenomaan kielellä ja kielen kanssa, ja tästä ollaan yleensä myös hyvin tietoisia. Tutkimuksesta käykin ilmi, että kielenhuoltoon suhtaudutaan myönteisesti ja että sitä pidetään tärkeänä.

Saviniemen tulokset ovat kiinnostavia sekä kieliasenteiden tutkimuksen että suomen kielen huollon kannalta ja osoittavat, että uudenlaisella tutkimusmenetelmien yhdistelmällä voi avata uusia näkökulmia näiden alojen tutkimukseen. Väitöskirja tuo myös yhden kielen ammattilaisten ryhmän kielenhuoltoasenteista uutta tietoa, jota voidaan hyödyntää laajemmin niin tulevassa kieliasenne- ja kielenhuoltotutkimuksessa kuin kielenhuollon opetuksessa ja toimittajien koulutuksessa. Analyysi ja tulokset esitetään selkeästi, ja niitä havainnollistetaan lukuisin kuvioin ja taulukoin. Työn laajuudesta sekä analyysin ja raportoinnin tarkkuudesta voi päätellä tutkijan työmäärän olleen suuri.

Maija Saviniemen väitöskirja on erinomaisesti kirjoitettu ja siksi miellyttävä lukea. Tekijä argumentoi johdonmukaisesti ja selkeästi. Hän on tietoinen aineiston ja analyysin sekä niistä tehtävien päätelmien mahdollisista rajoituksista ja ottaa ne hyvin huomioon. Työn keskeisenä antina pidän sitä, että se antaa uutta, entistä soveltavampaa suuntaa kielenhuollon ja kieliasenteiden tutkimukselle. Samalla se osoittaa, miten esimerkiksi kyselyaineistoa ja sisällönanalyysia voi hyödyntää ja yhdistellä muihin menetelmiin fennistisessä tutkimuksessa.

Anne Mäntynen

etunimi.k.sukunimi@jyu.fi

\section{Lähteet}

Fairclough, Norman 1992: Discourse and social change. Cambridge: Polity Press.

HeIKKINEN, VESA 1999: Ideologinen merkitys kriittisen tekstintutkimuksen teoriassa ja käytännössä. Helsinki: Suomalaisen Kirjallisuuden Seura.

HiddenmaA, Pirjo 2003: Suomen kieli who cares? Helsinki: Otava.

Karvonen, Pirjo 1995: Oppikirjateksti toimintana. Helsinki: Suomalaisen Kirjallisuuden Seura.

Kolehmainen, Taru 2014: Kielenhuollon juurilla. Suomen kielen ohjailun historiaa. Helsinki: Suomalaisen Kirjallisuuden Seura.

Leino, Pentti 1989: Kirjakieli - puutarha vai kansallispuisto? - Virittäjä 93 S. 554-571.

Mantila, Harri 2005: Kielikäsityksestä kielenhuollon uusiin periaatteisiin. - Kielikello 2/2005 s. 4-9.

Mielikäinen, Aila - Palander, MarJATTA 2014: Miten suomalaiset puhuvat murteista? Kansanlingvistinen tutkimus metakielestä. Helsinki: Suomalaisen Kirjallisuuden Seura.

Mäntynen, Anne 2003: Miten kielestä kerrotaan. Kielijuttujen retoriikkaa. Helsinki: Suomalaisen Kirjallisuuden Seura.

Nupponen, Anne-Maria 2011: "Savon murre" savolaiskorvin. Kansa murteen havainnoijana. Joensuu: Itä-Suomen yliopisto.

PAso, EıjA 2007: Työkyky merkitsee. Työkyvyn merkityksen ja maailman rakentuminen lehtiteksteissä. Acta Universitatis Ouluensis. B Humaniora 77. Oulu: Oulun yliopisto.

PäLli, PEKKA 2003: Ihmisryhmä diskurssissa 
ja diskurssina. Acta Universitatis Tamperensis 910. Tampere: Tampere University Press.

Rintala, Päıvi 1998: Kielikäsitys ja kielenohjailu. - Sananjalka 40 s. 47-64.

Sajava ara, Paula 2000: Kielenohjailu.

- Kari Sajavaara \& Arja Piirainen-

Marsh (toim.), Kieli, diskurssi \&

yhteisö s. 67-106. Jyväskylä: Jyväskylän

yliopisto, Soveltavan kielentutkimuksen keskus.
VaAttovaAra, Johanna 2009: Meän tapa puhua. Tornionlaakso pellolaisnuorten subjektiivisena paikkana ja murrealueena. Helsinki: Suomalaisen Kirjallisuuden Seura.

Vinikainen, TARU 2010: Taipuuko "akrobaatti Aleksandra"? Nimikekonstruktio ja nimikkeen taipuminen lehtikielessä 1900-luvulta 200o-luvulle. Joensuu: ItäSuomen yliopisto.

\section{Kattava kuvaus itämerensuomen balttilaislainoista}

\author{
Santeri Junttila: Tiedon kumuloituminen \\ ja trendit lainasanatutkimuksessa. Kanta- \\ suomen balttilaislainojen tutkimushistoria. \\ Helsinki: Helsingin yliopisto 2015. $291 \mathrm{~s}$. \\ ISBN 978-951-1841-7.
}

Itämerensuomalaisten ja balttilaisten kielten yhteisistä sanoista on tehty havaintoja jo ennen nykyaikaisen kielitieteen syntyä, mutta vasta $1800-$ luvulla pystyttiin kehittämään metodit, joiden avulla havaittujen yhtäläisyyksien laatua voitiin arvioida ja täsmentää. Uranuurtaja oli tanskalainen Vilhelm Thomsen, jonka klassinen teos Beröringer mellem de finske og de baltiske (litauisk-lettiske) Sprog: En sproghistorisk Undersøgelse ilmestyi Kööpenhaminassa vuonna 1890. Jo parikymmentä vuotta aiemmin Thomsen oli julkaissut vastaavan esityksen germaanisista lainoista (Thomsen 1870), joiden yhteydessä hän otti kantaa myös muutamiin balttilaisperäisiin sanoihin sekä kielikontakteihin yleisemmin. Kielellisen substanssin äkillisen karttumisen ohella ratkaiseva edistysaskel oli äännehistoriallinen kehys ja täsmällinen analyysimenetelmä, jolla Thomsen käsitteli aineistoaan. Työstä tuli esikuva ja lähtökohta itämerensuomalaiselle lainasana- tutkimukselle. Santeri Junttila on väitöskirjassaan selvittänyt, mitä kansainvälinen tiedeyhteisö Thomsenista alkaen on saanut aikaan balttilaislainojen tutkimuksen alalla vuoteen 2009 mennessä. Tutkimuksen aineistona ovat kaikki ne itämerensuomalaiset sanat, joille on vähintään kerran ehdotettu balttilaista lainaetymologiaa.

\section{Väitöskirjan rakenne}

Junttila on jakanut väitöskirjansa viiteen päälukuun. Näistä ensimmäinen on johdanto, jossa selostetaan työn tavoitteet, aiemman tutkimuksen pääkohdat, aineiston rajaukset sekä esitystavat ja työn rakenne. Toisessa luvussa määritellään, mitä tarkoittavat kantasuomi, balttilaisuus ja lainaetymologia. Lisäksi selvitetään, miten lainaetymologioiden määrä on tutkimuksessa laskettu. Se on olennaista työssä, jossa kvantitatiivisilla seikoilla on keskeinen osuus.

Luvussa 3 esitellään aineiston balttilaiset lainaetymologiat sekä niiden saama vastaanotto tiedeyhteisössä. Ensin tarkastellaan alkuperämainintojen tyyppejä. Junttila tähdentää, että pelkkä väite sanan balttilaisesta alkuperästä ei vielä tee siitä 